\title{
Response of Foliar Supplementation of N, P and K Fertilizers on Yield and Economics of Pearl Millet
}

\author{
Surgyan Rundla* and R.C. Bairwa \\ Department of Agronomy, College of Agriculture (SKRAU), Bikaner-334 006, India \\ *Corresponding author
}

\section{A B S T R A C T}

\begin{abstract}
An experiment was conducted during rainy season of 2016 at Agronomy Farm of College of Agriculture, Bikaner (Rajasthan) to study the 'Response of foliar supplementation of N, $\mathrm{P}$ and $\mathrm{K}$ fertilizers on yield and economics of pearl millet [Pennisetum glaucum (L.)]

Keywords

$\mathrm{N}, \mathrm{P}$ and $\mathrm{K}$ fertilizes, Pearl millet

Article Info

Accepted:

10 March 2018

Available Online:

10 April 2018

hybrid RHB-177. The study comprised of 14 treatments of different N, P and K fertilizers applied as basal, top dressing and foliar application in randomized block design replicated thrice. Urea, DAP and $\mathrm{KCl}$ were used for basal application and urea as top dressing. Foliar spray of NPK (18:18:18) was done at 25 DAS and 35 DAS and urea $(0.5,1.0$ and $1.5 \%)$ at 35 DAS. The results revealed that application of $75 \% \mathrm{~N}(50 \%$ basal $+25 \%$ top dressing at 25 DAS): $\mathrm{P}: \mathrm{K}+1.5 \%$ spray of NPK $(18: 18: 18)$ at 35 DAS $\left(\mathrm{T}_{11}\right)$ recorded significantly higher total number of tillers/ plant at 60 DAS (5.05), number of effective tillers/ plant (2.91), ear head weight (32.39 g), grain weight/ ear head (23.32 g), test weight (10.31 g), grain yield $\left(2134 \mathrm{~kg} \mathrm{ha}^{-1}\right)$, stover yield $\left(4744 \mathrm{~kg} \mathrm{ha}^{-1}\right)$ of biological yield $\left(6878 \mathrm{~kg} \mathrm{ha}^{-1}\right)$ and of pearl millet. The highest harvest index $(31.94 \%)$ was recorded with $50 \%$ as basal $(\mathrm{NPK})+1.5 \%$ spray of NPK $(18: 18: 18)$ at $35 \mathrm{DAS}\left(\mathrm{T}_{8}\right)$ which was significantly higher over $\mathrm{T}_{1}, \mathrm{~T}_{3}, \mathrm{~T}_{4}$ and $\mathrm{T}_{5}$. The significantly highest gross return $\left(₹ 42798 \mathrm{ha}^{-1}\right.$ ), net return ( $₹ 23026$ $\mathrm{ha}^{-1}$ ) and benefit: cost ratio (2.16) were also obtained with the application of $75 \% \mathrm{~N}(50 \%$ basal+25\% top dressing at 25 DAS $)$ : P: $\mathrm{K}+1.5 \%$ spray of NPK (18:18:18) at 35 DAS $\left(\mathrm{T}_{11}\right)$.
\end{abstract}

\section{Introduction}

Pearl millet [Pennisetum glaucum (L.)] is an important cereal crop of arid and semi-arid regions of India. It is popularly known as Bajra and being drought tolerant generally grown as rainfed crop on marginal lands under low input management conditions. However, it responds well to good management practices and higher soil fertility levels. Rajasthan is one of the leading states in area (4.0 mha) and production of pearl millet (4.4 MT) however; the average productivity is only $10.93 \mathrm{q} \mathrm{ha}^{-1}$
(Anonymous, 2015-16). The main causes of low productivity are prevailing abiotic stresses like drought, poor soil fertility, high soil $\mathrm{pH}$ and high temperature. These factors limit the uptake of applied nutrients by roots and also do not able to turn over the nutrients commensurate with crop nutritional requirement at different growth stages.

Balanced nutrition played an imported role in boosting the productivity of pearl millet (Narolia and Poonia, 2011). Integrated use of chemical fertilizers (N, P and $\mathrm{K}$ ) through 
foliar feeding has been accepted an effective way to compensate soil deficiency and inability of soil to transfer nutrients to the plants to maintain high productivity of undernourished crop (Pareek and Chandra, 2007). Therefore, the present experiment was undertaken in order to increase the productivity of pearl millet by efficient use of inorganic fertilizers applied through foliar feeding of N, P and K nutrients alone and/ or in combination with soil application.

\section{Materials and Methods}

The field experiment was conducted during rainy season of 2016 at Agronomy Farm of College of Agriculture, Bikaner $\left(28^{0} 01^{1} \mathrm{~N}\right.$ and $73^{0} 22^{1} \mathrm{E}$ at $234.7 \mathrm{~m}$ above mean sea level). Soil of the experimental plot was loamy sand in texture, alkaline in reaction $(\mathrm{pH} 8.5)$ with low organic carbon $(0.11 \%)$. The available soil N, P and $\mathrm{K}$ were 120.30, 20.12 and 223.70 $\mathrm{kg} \mathrm{ha}^{-1}$, respectively. The experiment was laid out in Randomized Block Design (RBD) with 3 replications. The treatments comprised 14 combinations viz., control, recommended dose of NPK (60:40:20 kg ha-1), $0.5 \%$ spray of NPK (18:18:18) at 25 and 35 DAS, $1.0 \%$ spray of NPK (18:18:18) at 25 and 35 DAS, $1.5 \%$ spray of NPK $(18: 18: 18)$ at 25 and 35 DAS, $50 \%$ as basal (NPK) $+0.5 \%$ spray of NPK (18:18:18) at 35 DAS, $50 \%$ as basal (NPK)+1.0\% spray of NPK $(18: 18: 18)$ at 35 DAS, $50 \%$ as basal (NPK) $+1.5 \%$ spray of NPK (18:18:18) at 35 DAS, $75 \%$ N (50\% basal $+25 \%$ top dressing at $25 \mathrm{DAS}): \mathrm{P}: \mathrm{K}$ as basal+0.5\% spray of NPK $(18: 18: 18)$ at 35 DAS, $75 \% \mathrm{~N}$ (50\% basal+25\% top dressing at 25 DAS):P:K as basal+1.0\% spray of NPK $(18: 18: 18)$ at 35 DAS, $75 \% \quad \mathrm{~N} \quad(50 \%$ basal $+25 \%$ top dressing at 25 DAS) $: \mathrm{P}_{2} \mathrm{O}_{5}: \mathrm{K}_{2} \mathrm{O}$ as basal+1.5\% spray of NPK (18:18:18) at 35 DAS, $50 \% \mathrm{~N}+100 \%(\mathrm{P}$ and $\mathrm{K}$ ) as basal $+0.5 \%$ of urea at $35 \mathrm{DAS}, 50 \% \mathrm{~N}+100 \%$ ( $\mathrm{P}$ and $\mathrm{K}$ ) as basal $+1.0 \%$ of urea at $35 \mathrm{DAS}$ and $50 \%$ $\mathrm{N}+100 \%(\mathrm{P}$ and $\mathrm{K})$ as basal $+1.5 \%$ of urea at
35 DAS. The recommended dose was applied as basal $\left(30 \mathrm{~kg} \mathrm{~N}^{-1}, 40 \mathrm{~kg} \mathrm{P}_{2} \mathrm{O}_{5} \mathrm{ha}^{-1}\right.$ and 20 $\mathrm{kg} \mathrm{K}_{2} \mathrm{O} \mathrm{ha}^{-1}$ ) through urea, DAP and $\mathrm{KCl}$. The remaining $30 \mathrm{~kg} \mathrm{~N} \mathrm{ha}^{-1}$ was top dressed at 25 DAS through urea. Urea, DAP and $\mathrm{KCl}$ were used for basal application and urea as top dressing. Foliar spray of NPK (18:18:18 @ $0.5,1.0$ and $1.5 \%$ ) was done at 25 DAS and 35 DAS and urea $(0.5,1.0$ and $1.5 \%)$ at 35 DAS in early morning hours with knapsack sprayer.

Sowing of pearl millet hybrid RHB-177 was done on $2^{\text {nd }}$ July 2016 using seed rate of $4 \mathrm{~kg}$ $\mathrm{ha}^{-1}$ and maintained crop geometry of $45 \times 12$ $\mathrm{cm}$. The size of individual plot was kept $4.5 \mathrm{x}$ $4.0 \mathrm{~m}$. The rainfall received during growing period (July to September) was $335.3 \mathrm{~mm}$ in 20 rainy days. The mean weekly minimum and maximum temperature during the crop season fluctuated from 23.5 to $40.8^{0} \mathrm{C}$ with average relative humidity from 29.3 to $88.1 \%$. Experimental crop was raised as per recommended package of practices. Two irrigations with sprinkler were applied during the dry spell observed at milking stage and pre maturing stage.

Observations on total number of tillers/ plant at 60 DAS (days after sowing), number of effective tillers/ plant, ear head weight (g), grain weight/ ear head $(\mathrm{g})$, test weight $(\mathrm{g})$, grain yield $\left(\mathrm{kg} \mathrm{ha}^{-1}\right)$, stover yield $\left(\mathrm{kg} \mathrm{ha}^{-1}\right)$, biological yield $\left(\mathrm{kg} \mathrm{ha}^{-1}\right)$ and harvest index (\%) were recorded. Stover yield $\left(\mathrm{kg} \mathrm{plot}^{-1}\right)$ was obtained by subtracting the seed yield from biological yield plot $^{-1}$ recorded earlier and then converted in terms of $\mathrm{kg} \mathrm{ha}^{-1}$. The harvested material from each plot was thoroughly sun dried and weighed to record biological yield. Harvest index (HI) was calculated as per the procedure prescribed by Singh and Stoskopf (1971). Economics of each treatment was worked out on prevailing market price of input and output in terms of net returns $\left(₹ \mathrm{ha}^{-1}\right)$ and $\mathrm{B}$ : $\mathrm{C}$ ratio to compare the profitability of different treatments. The 
recorded data were subjected to statistical analysis following standard procedure as suggested by Fisher (1950).

\section{Results and Discussion}

\section{Effect on yield parameters and yield}

The data presented in Table 1 revealed that application of $\mathrm{N}, \mathrm{P}$ and $\mathrm{K}$ significantly influences the yield parameters of pearl millet. Application of $75 \% \mathrm{~N}(50 \%$ basal $+25 \%$ top dressing at 25 DAS):P:K+1.5\% spray of NPK $(18: 18: 18)$ at 35 DAS $\left(\mathrm{T}_{11}\right)$ resulted in significantly higher total number of tillers/ plant at 60 DAS (5.05) which was $51.70 \%$ high as compared to $\mathrm{T}_{1}$ (3.33 tillers/ plant), $\mathrm{T}_{3}$, $\mathrm{T}_{4}, \mathrm{~T}_{5}, \mathrm{~T}_{6}, \mathrm{~T}_{7}, \mathrm{~T}_{8}, \mathrm{~T}_{12}, \mathrm{~T}_{13}$ and $\mathrm{T}_{14}$. However, it was found statistically at par with $\mathrm{T}_{3}, \mathrm{~T}_{9}$ and $\mathrm{T}_{10}$ treatments. $\mathrm{T}_{11}$ treatment gave the maximum number of effective tillers/ plant (2.91) which indicated an increase of $34.67 \%$ over $\mathrm{T}_{1}$ and at par with $\mathrm{T}_{2}, \mathrm{~T}_{9}$ and $\mathrm{T}_{10}$ but significantly higher over $\mathrm{T}_{1}$ and rest of the treatments. Significantly higher ear head weight was recorded with $\mathrm{T}_{11}(32.39 \mathrm{~g})$ over $\mathrm{T}_{1}, \mathrm{~T}_{3}, \mathrm{~T}_{4}, \mathrm{~T}_{5}, \mathrm{~T}_{6}, \mathrm{~T}_{12}$ and $\mathrm{T}_{13}$ which was $12.97,15.21,21.71,33.02,25.64,27.10$ and $32.73 \%$ higher, respectively and at par rest with $\mathrm{T}_{2}, \mathrm{~T}_{7}, \mathrm{~T}_{8} \mathrm{~T}_{9}$ and $\mathrm{T}_{10}$ treatments. There was significant difference among fertilizer application with respect to grain weight/ ear head and $T_{11}$ produced maximum grain weight/ ear head (23.32 g), which was significantly higher over $\mathrm{T}_{1}, \mathrm{~T}_{3}, \mathrm{~T}_{4}, \mathrm{~T}_{5}, \mathrm{~T}_{6}, \mathrm{~T}_{7}$, $\mathrm{T}_{8}, \mathrm{~T}_{12}, \mathrm{~T}_{13}, \mathrm{~T}_{14}$ and at par with rest of the treatments $\left(\mathrm{T}_{2}, \mathrm{~T}_{9}\right.$ and $\left.\mathrm{T}_{10}\right)$. Likewise $\mathrm{T}_{11}$ resulted in maximum test weight $(10.31 \mathrm{~g})$ of pearl millet, which significantly higher over $\mathrm{T}_{1} \quad(86.43 \%$ higher) and other treatments except $\mathrm{T}_{2}, \mathrm{~T}_{9}$ and $\mathrm{T}_{10}$.

A glimpse of data (Table 2) indicated that the highest grain yield (2134 $\mathrm{kg} \mathrm{ha}^{-1}$ ) and stover yield (4744 $\mathrm{kg} \mathrm{ha}^{-1}$ ) was recorded with the application of $75 \% \mathrm{~N}(50 \%$ basal $+25 \%$ top dressing at 25 DAS):P:K+1.5\% spray of NPK $(18: 18: 18)$ at 35 DAS $\left(\mathrm{T}_{11}\right)$ which was significantly higher over $\mathrm{T}_{1}, \mathrm{~T}_{3}, \mathrm{~T}_{4}, \mathrm{~T}_{5}, \mathrm{~T}_{6}, \mathrm{~T}_{7}$, $\mathrm{T}_{8}, \mathrm{~T}_{12}, \mathrm{~T}_{13}$ and $\mathrm{T}_{14}$, but at par with $\mathrm{T}_{2}, \mathrm{~T}_{9}$ and $\mathrm{T}_{10}$. Application of $75 \% \mathrm{~N}(50 \%$ basal $+25 \%$ top dressing at $25 \mathrm{DAS}): \mathrm{P}: \mathrm{K}+1.5 \%$ spray of NPK (18:18:18) at 35 DAS $\left(\mathrm{T}_{11}\right)$ increased yield by $72.32 \%$ over $\mathrm{T}_{1}$. Application of $75 \%$ $\mathrm{N} \quad(50 \%$ basal $+25 \%$ top dressing at 25 DAS):P:K+1.5\% spray of NPK $(18: 18: 18)$ at 35 DAS $\left(\mathrm{T}_{11}\right)$ was found to be at par with $75 \%$ $\mathrm{N}$ (50\% basal+25\% top dressing at 25 DAS):P:K+0.5\% spray of NPK $(18: 18: 18)$ at 35 DAS $\left(\mathrm{T}_{9}\right)$ and $75 \% \mathrm{~N}(50 \%$ basal $+25 \%$ top dressing at $25 \mathrm{DAS}): \mathrm{P}: \mathrm{K}+1.0 \%$ spray of NPK (18:18:18) at 35 DAS $\left(\mathrm{T}_{10}\right)$, but significantly higher over remaining treatments. $\mathrm{T}_{11}$ treatment also increased biological yield $72.32 \%$ over $\mathrm{T}_{1}$ which was at par with $\mathrm{T}_{9}$ and $\mathrm{T}_{10}$, but significantly higher over remaining treatments. The highest harvest index $(31.94 \%)$ was recorded with $50 \%$ as basal $(\mathrm{NPK})+1.5 \%$ spray of NPK $(18: 18 ; 18)$ at 35 DAS $\left(\mathrm{T}_{8}\right)$ which was significantly higher over $\mathrm{T}_{1}, \mathrm{~T}_{3}, \mathrm{~T}_{4}$ and $\mathrm{T}_{5}$ however; it was statistically at par with other remaining treatments.

The increased supply of NPK and their higher uptake by plants might have stimulated the rate of various physiological processes in plant and led to increased yield. Foliar supplementation of $\mathrm{N}, \mathrm{P}$ and $\mathrm{K}$ might compensate for soil deficiencies and soil's inability to transfer nutrients to the plants and furthermore higher efficiency of foliar supply of N, P and $\mathrm{K}$ can further boost photosynthetic efficiency by delaying the onset of leaf senescence which improved the yield and yield parameters of pearl millet. The results of present investigation are in close agreements with the findings of Chaudhari et al., (2002), Bhowmick (2006), Rathore et al., (2006), Sritharan et al., (2006), Choudhary and Gautam (2007), Kanzaria et al., (2010), Ansari et al., (2011), Narolia and Poonia (2011) and Zaki et al., (2016). 
Table.1 Effect of N, P and K fertilizers on yield parameters of pearl millet

\begin{tabular}{|c|c|c|c|c|c|c|}
\hline \multicolumn{2}{|r|}{ Treatment } & \multirow{2}{*}{$\begin{array}{l}\text { Total } \\
\text { no. of } \\
\text { tillers } \\
\text { plant } \\
\text { at } 60 \\
\text { DAS } \\
3.33\end{array}$} & \multirow{2}{*}{$\begin{array}{l}\text { No. of } \\
\text { effective } \\
\text { tillers }^{-1} \\
\text { plant }^{-1} \\
1.83\end{array}$} & \multirow{2}{*}{$\begin{array}{c}\begin{array}{c}\text { Ear } \\
\text { head } \\
\text { weight } \\
(\mathrm{g})\end{array} \\
21.39\end{array}$} & \multirow{2}{*}{$\begin{array}{l}\text { Grain } \\
\text { weight per } \\
\text { ear head } \\
(\mathrm{g}) \\
14.18\end{array}$} & \multirow{2}{*}{$\begin{array}{c}\text { Test } \\
\text { weight } \\
(\mathrm{g})\end{array}$} \\
\hline $\mathbf{T}_{1}$ & Control & & & & & \\
\hline $\mathbf{T}_{2}$ & Recommended dose of NPK (60:40:20 kg ha $\left.{ }^{-1}\right)$ & 4.70 & 2.84 & 30.59 & 21.34 & 9.71 \\
\hline $\mathbf{T}_{\mathbf{3}}$ & $0.5 \%$ spray of NPK $(18: 18: 18)$ at 25 and 35 DAS & 3.64 & 2.17 & 24.16 & 16.70 & 8.54 \\
\hline $\mathbf{T}_{4}$ & $1.0 \%$ spray of NPK $(18: 18: 18)$ at 25 and 35 DAS & 3.69 & 2.22 & 24.64 & 17.13 & 8.57 \\
\hline $\mathbf{T}_{\mathbf{5}}$ & $1.5 \%$ spray of NPK $(18: 18: 18)$ at 25 and 35 DAS & 3.72 & 2.24 & 26.03 & 17.50 & 8.65 \\
\hline $\mathrm{T}_{6}$ & $50 \%$ as basal (NPK)+0.5\% spray of NPK $(18: 18: 18)$ at 35 DAS & 4.11 & 2.63 & 28.45 & 18.89 & 8.83 \\
\hline $\mathbf{T}_{7}$ & $50 \%$ as basal $(\mathrm{NPK})+1.0 \%$ spray of NPK $(18: 18: 18)$ at 35 DAS & 4.25 & 2.65 & 30.84 & 20.19 & 8.91 \\
\hline $\mathbf{T}_{8}$ & $50 \%$ as basal (NPK)+1.5\% spray of NPK $(18: 18: 18)$ at 35 DAS & 4.30 & 2.66 & 30.94 & 20.55 & 8.96 \\
\hline$T_{9}$ & $\begin{array}{l}75 \% \mathrm{~N}(50 \% \text { basal }+25 \% \text { top dressing at } 25 \mathrm{DAS}): \mathrm{P}: \mathrm{K}+0.5 \% \\
\text { spray of NPK (18:18:18) at } 35 \mathrm{DAS}\end{array}$ & 4.75 & 2.86 & 31.50 & 22.08 & 9.96 \\
\hline $\mathbf{T}_{10}$ & $\begin{array}{l}75 \% \mathrm{~N}(50 \% \text { basal }+25 \% \text { top dressing at } 25 \mathrm{DAS}): \mathrm{P}: \mathrm{K}+1.0 \% \\
\text { spray of NPK (18:18:18) at } 35 \text { DAS }\end{array}$ & 4.83 & 2.88 & 31.79 & 22.41 & 10.12 \\
\hline $\mathbf{T}_{11}$ & $\begin{array}{l}75 \% \mathrm{~N}(50 \% \text { basal }+25 \% \text { top dressing at } 25 \mathrm{DAS}): \mathrm{P}: \mathrm{K}+1.5 \% \\
\text { spray of NPK (18:18:18) at } 35 \mathrm{DAS}\end{array}$ & 5.05 & 2.91 & 32.39 & 23.32 & 10.31 \\
\hline $\mathbf{T}_{12}$ & $50 \% \mathrm{~N}+100 \%(\mathrm{P}$ and $\mathrm{K})$ as basal $+0.5 \%$ urea at $35 \mathrm{DAS}$ & 4.23 & 2.67 & 26.87 & 19.25 & 9.15 \\
\hline $\mathbf{T}_{13}$ & $50 \% \mathrm{~N}+100 \%(\mathrm{P}$ and $\mathrm{K})$ as basal+1.0\% urea at $35 \mathrm{DAS}$ & 4.29 & 2.69 & 27.19 & 19.30 & 9.31 \\
\hline \multirow[t]{3}{*}{$\mathbf{T}_{14}$} & $50 \% \mathrm{~N}+100 \%(\mathrm{P}$ and $\mathrm{K})$ as basal $+1.5 \%$ urea at $35 \mathrm{DAS}$ & 4.33 & 2.72 & 28.39 & 19.65 & 9.37 \\
\hline & $\mathrm{SEm} \pm$ & 0.15 & 0.06 & 1.03 & 0.88 & 0.25 \\
\hline & $\mathrm{CD}(0.05)$ & 0.42 & 0.17 & 2.98 & 2.57 & 0.73 \\
\hline
\end{tabular}


Table.2 Effect of N, P and K fertilizers on yield and harvest index of pearl millet

\begin{tabular}{|c|c|c|c|c|c|}
\hline \multicolumn{2}{|r|}{ Treatment } & \multicolumn{3}{|c|}{ Yield $\left(\mathrm{kg} \mathrm{ha}^{-1}\right)$} & \multirow{3}{*}{$\begin{array}{c}\text { Harvest } \\
\text { index (\%) } \\
26.82\end{array}$} \\
\hline & & \multirow{2}{*}{$\begin{array}{c}\text { Grain } \\
1067\end{array}$} & \multirow{2}{*}{$\begin{array}{c}\text { Stover } \\
2924\end{array}$} & \multirow{2}{*}{$\begin{array}{c}\text { Biological } \\
3991\end{array}$} & \\
\hline $\mathbf{T}_{1}$ & Control & & & & \\
\hline $\mathbf{T}_{2}$ & Recommended dose of NPK $\left(60: 40: 20 \mathrm{~kg} \mathrm{ha}^{-1}\right)$ & 2010 & 4506 & 6516 & 30.88 \\
\hline $\mathbf{T}_{\mathbf{3}}$ & $0.5 \%$ spray of NPK $(18: 18: 18)$ at 25 and 35 DAS & 1257 & 3401 & 4657 & 26.99 \\
\hline $\mathbf{T}_{4}$ & $1.0 \%$ spray of NPK $(18: 18: 18)$ at 25 and 35 DAS & 1270 & 3509 & 4779 & 26.58 \\
\hline $\mathbf{T}_{\mathbf{5}}$ & $1.5 \%$ spray of NPK $(18: 18: 18)$ at 25 and 35 DAS & 1288 & 3510 & 4798 & 26.93 \\
\hline $\mathrm{T}_{6}$ & $50 \%$ as basal $(\mathrm{NPK})+0.5 \%$ spray of NPK $(18: 18: 18)$ at $35 \mathrm{DAS}$ & 1753 & 3856 & 5608 & 31.22 \\
\hline $\mathbf{T}_{7}$ & $50 \%$ as basal $(\mathrm{NPK})+1.0 \%$ spray of NPK $(18: 18: 18)$ at $35 \mathrm{DAS}$ & 1847 & 4024 & 5871 & 31.44 \\
\hline $\mathbf{T}_{8}$ & $50 \%$ as basal $(\mathrm{NPK})+1.5 \%$ spray of NPK $(18: 18: 18)$ at 35 DAS & 1892 & 4025 & 5917 & 31.94 \\
\hline $\mathbf{T}_{9}$ & $\begin{array}{l}75 \% \mathrm{~N}(50 \% \text { basal }+25 \% \text { top dressing at } 25 \mathrm{DAS}): \mathrm{P}: \mathrm{K}+0.5 \% \\
\text { spray of NPK }(18: 18: 18) \text { at } 35 \mathrm{DAS}\end{array}$ & 2029 & 4524 & 6553 & 30.96 \\
\hline $\mathbf{T}_{10}$ & $\begin{array}{l}75 \% \mathrm{~N}(50 \% \text { basal }+25 \% \text { top dressing at } 25 \mathrm{DAS}): \mathrm{P}: \mathrm{K}+1.0 \% \\
\text { spray of NPK (18:18:18) at } 35 \mathrm{DAS}\end{array}$ & 2115 & 4674 & 6789 & 31.19 \\
\hline $\mathbf{T}_{11}$ & $\begin{array}{l}75 \% \mathrm{~N}(50 \% \text { basal }+25 \% \text { top dressing at } 25 \mathrm{DAS}): \mathrm{P}: \mathrm{K}+1.5 \% \\
\text { spray of NPK (18:18:18) at } 35 \mathrm{DAS}\end{array}$ & 2134 & 4744 & 6878 & 31.07 \\
\hline $\mathbf{T}_{12}$ & $50 \% \mathrm{~N}+100 \%(\mathrm{P}$ and $\mathrm{K})$ as basal+0.5\% urea at $35 \mathrm{DAS}$ & 1748 & 3894 & 5642 & 31.13 \\
\hline $\mathbf{T}_{13}$ & $50 \% \mathrm{~N}+100 \%(\mathrm{P}$ and $\mathrm{K})$ as basal+1.0\% urea at $35 \mathrm{DAS}$ & 1807 & 4193 & 6001 & 30.19 \\
\hline \multirow[t]{4}{*}{$\mathrm{T}_{14}$} & $50 \% \mathrm{~N}+100 \%(\mathrm{P}$ and $\mathrm{K})$ as basal+1.5\% urea at $35 \mathrm{DAS}$ & 1889 & 4139 & 6028 & 31.31 \\
\hline & $\mathrm{SEm} \pm$ & 46 & 105 & 124 & 0.68 \\
\hline & $\mathrm{CD}(0.05)$ & 133 & 306 & 359 & 1.98 \\
\hline & CV (\%) & 7.98 & 7.92 & 6.49 & 6.83 \\
\hline
\end{tabular}


Table.3 Effect of N, P and K fertilizers on economics of pearl millet

\begin{tabular}{|c|c|c|c|c|c|}
\hline \multicolumn{2}{|c|}{ Treatment } & \multirow{2}{*}{$\begin{array}{c}\begin{array}{c}\text { Cost of } \\
\text { cultivation } \\
\left(₹ h a^{-1}\right)\end{array} \\
16080\end{array}$} & \multirow{2}{*}{$\begin{array}{l}\text { Gross returns } \\
\qquad \begin{array}{l}\left(₹ \mathrm{ha}^{-1}\right) \\
22787\end{array}\end{array}$} & \multirow{2}{*}{$\begin{array}{l}\text { Net returns } \\
\qquad \begin{array}{l}\left(\mathrm{Fa}^{-1}\right) \\
6707\end{array}\end{array}$} & \multirow{2}{*}{$\begin{array}{l}\mathrm{B}: \mathrm{C} \\
\text { ratio } \\
1.31\end{array}$} \\
\hline $\mathbf{T}_{1}$ & Control & & & & \\
\hline $\mathbf{T}_{2}$ & Recommended dose of NPK $\left(60: 40: 20 \mathrm{~kg} \mathrm{ha}^{-1}\right)$ & 19323 & 40412 & 21089 & 2.09 \\
\hline $\mathbf{T}_{\mathbf{3}}$ & $0.5 \%$ spray of NPK $(18: 18: 18)$ at 25 and 35 DAS & 17420 & 26725 & 9305 & 1.53 \\
\hline $\mathbf{T}_{4}$ & $1.0 \%$ spray of NPK $(18: 18: 18)$ at 25 and 35 DAS & 17960 & 27187 & 9227 & 1.51 \\
\hline $\mathbf{T}_{5}$ & $1.5 \%$ spray of NPK $(18: 18: 18)$ at 25 and 35 DAS & 18500 & 27453 & 8953 & 1.48 \\
\hline $\mathbf{T}_{6}$ & $\begin{array}{l}50 \% \text { as basal }(\mathrm{NPK})+0.5 \% \text { spray of NPK }(18: 18: 18) \text { at } \\
35 \text { DAS }\end{array}$ & 18471 & 35056 & 16584 & 1.90 \\
\hline $\mathbf{T}_{7}$ & $\begin{array}{l}50 \% \text { as basal }(\mathrm{NPK})+1.0 \% \text { spray of NPK }(18: 18: 18) \text { at } \\
35 \text { DAS }\end{array}$ & 18741 & 36837 & 18095 & 1.97 \\
\hline $\mathbf{T}_{\mathbf{8}}$ & $\begin{array}{l}50 \% \text { as basal }(\mathrm{NPK})+1.5 \% \text { spray of NPK }(18: 18: 18) \text { at } \\
35 \text { DAS }\end{array}$ & 19011 & 37492 & 18480 & 1.97 \\
\hline$T_{9}$ & $\begin{array}{l}75 \% \mathrm{~N}(50 \% \text { basal+25\% top dressing at } 25 \\
\text { DAS }): P: K+0.5 \% \text { spray of NPK }(18: 18: 18) \text { at } 35 \text { DAS }\end{array}$ & 19232 & 40728 & 21496 & 2.12 \\
\hline$\overline{T_{10}}$ & $\begin{array}{l}75 \% \quad \mathrm{~N}(50 \% \text { basal+25\% top dressing at } 25 \\
\text { DAS }): P: K+1.0 \% \text { spray of NPK }(18: 18: 18) \text { at } 35 \text { DAS }\end{array}$ & 19502 & 42353 & 22851 & 2.17 \\
\hline $\mathbf{T}_{11}$ & $\begin{array}{l}75 \% \mathrm{~N}(50 \% \text { basal+25\% top dressing at } 25 \\
\text { DAS }): P: K+1.5 \% \text { spray of NPK }(18: 18: 18) \text { at } 35 \text { DAS }\end{array}$ & 19772 & 42798 & 23026 & 2.16 \\
\hline $\mathbf{T}_{12}$ & $50 \% \mathrm{~N}+100 \%(\mathrm{P}$ and $\mathrm{K})$ as basal+0.5\% urea at $35 \mathrm{DAS}$ & 19350 & 35076 & 15726 & 1.81 \\
\hline $\mathbf{T}_{13}$ & $50 \% \mathrm{~N}+100 \%(\mathrm{P}$ and $\mathrm{K})$ as basal+1.0\% urea at $35 \mathrm{DAS}$ & 19368 & 36691 & 17323 & 1.89 \\
\hline $\mathbf{T}_{14}$ & $50 \% \mathrm{~N}+100 \%(\mathrm{P}$ and $\mathrm{K})$ as basal+1.5\% urea at $35 \mathrm{DAS}$ & 19386 & 37741 & 18355 & 1.95 \\
\hline & $\mathrm{SEm} \pm$ & - & 765 & 765 & 0.04 \\
\hline & $\mathrm{CD}(0.05)$ & - & 2225 & 2225 & 0.12 \\
\hline
\end{tabular}




\section{Effect on economics}

Economics of the treatments presented in Table 3 revealed that the gross return ( $₹ 42798 \mathrm{ha}^{-1}$ ), net return ( $₹ 23026 \mathrm{ha}^{-1}$ ) and benefit: cost ratio (2.16) were higher with the application of $75 \% \mathrm{~N}(50 \%$ basal+25\% top dressing at 25 DAS): $\mathrm{P}: \mathrm{K}+1.5 \%$ spray of NPK (18:18:18) at 35 DAS $\left(\mathrm{T}_{11}\right)$.

It was found to be at par with $\mathrm{T}_{2}, \mathrm{~T}_{9}$ and $\mathrm{T}_{10}$ and significantly higher over control and other remaining treatments. The lowest gross return (₹22787), net return (₹6707) and B: C ratio (1.31) were recorded in the control.

These findings are in vicinity with those reported by Parihar et al., (2009) and Narolia and Poonia (2011).

\section{References}

Anonymous 2015-16. Economic Survey, Government of India, Ministry of Finance and Company Affairs, Economic Division, New Delhi.

Ansari, M.A., Rana, K.S., Rana, D.S. and Kumar, P. 2011. Effect of nutrient management and anti-transpirant on rainfed sole and intercropped pearlmillet (Pennisetum glaucum) and pigeonpea (Cajanus cajan). Indian Journal of Agronomy, 56(3):209216.

Bhowmick, M.K. 2006. Foliar nutrition and basal fertilization in chickpea under rainfed condition. Environment and Ecology, 24S (Special 4): 1028-1030.

Chaudhari, A.C., Meena, N.L. and Jat, R.L. 2002. Effect of nitrogen and moisture conservation practices on growth and yield of rainfed pearl millet. Annals Agriculture Research, 23(2): 223-225.

Choudhary, R.S. and Gautam, R.C. 2007. Effect of nutrient-management practices on growth and yield of pearl millet. Indian Journal of Agronomy, 52(1):64-66.
Fisher, R.A. 1950. Statistical Methods for Research Workers. Oliver and Boyd. Edinburg, Landon (U.K.).

Kanzaria, K.K., Sutaria, G.S., Akbari, K.N., Vora, V.D. and Padmani, D.R. 2010. Effect of integrated nutrient management on productivity of pearl millet and soil fertility of sandy loam soils under rainfed conditions. An Asian Journal of Soil Science, 5(1): 154-156.

Narolia, R.S. and Poonia, B.L. 2011. Growth dynamics, yield and economics of pearl millet (Pennisetum glaucum) as influenced by vermicompost and fertilizers. Annals of Arid Zone, 50(2): 145-149.

Parihar, C.M., Rana, K.S. and Parihar, M.D. 2009. Crop productivity, quality and nutrient uptake of pearlmillet (Pennisetum glaucum)-Indian mustard (Brassica juncea) cropping system as influenced by land configuration and direct and residual effect of nutrient management. Indian Journal of Agricultural Science, 79(11):927-930.

Rathore, V.S., Singh, P. and Gautam, R.C. 2006. Productivity and water use efficiency of rainfed pearl millet (Pennisetum glaucum L.) as influenced by planting patterns and integrated nutrient management. Indian Journal of Agronomy, 51(1): 46-48.

Singh, I.D. and Stoskopf, N.C. 1971. Harvest index in cereals. Agronomy Journal, 63: 224-226.

Sritharan, N., Anitha, R., Rajavel, M., Karthik, M. and Vanangamudi, M. 2006. Physiological manipulation for yield improvement in black gram (Vigna mungo L.) through foliar sprays of chemicals and plant growth regulator. Plant Archives, 6(2):803-806.

Zaki, M., Nabila Hassanein, M.S., Ahmed, A.G., Ahmed, M.A. and Hozayn, M. 2016. Impact of urea and potassium foliar application on yield and yield components of two maize hybrids. International Journal of Chemtech Research, 9(07): 300-307.

\section{How to cite this article:}

Surgyan Rundla and Bairwa, R.C. 2018. Response of Foliar Supplementation of N, P and K Fertilizers on Yield and Economics of Pearl Millet. Int.J.Curr.Microbiol.App.Sci. 7(04): 1203-1209. doi: https://doi.org/10.20546/ijcmas.2018.704.133 